\title{
An Analysis of Ideology in Translation on Bilingual Story Book for Children
}

\author{
Tania Syafutri \\ Universitas Bengkulu \\ taniajimin@yahoo.com \\ Iis Sujarwati \\ Universitas Bengkulu \\ iissujarwati@unib.ac.id
}

\begin{abstract}
This research analyzed the methods, techniques, and ideology in translation on bilingual story book for children entitled "Little Sunshine Bilingual Book. Kumpulan Lagu dan Cerita AnakAnak Dwibahasa." The theories were used in this research are from Newmark, Molina Albir, and Venuti. This research intended to analyze the techniques, methods, and ideology in translation on "Little Sunshine Bilingual Book. Kumpulan Lagu dan Cerita Anak- Anak Dwibahasa." This research was used descriptive qualitative method because the researcher want to analyze verbal text in written form of "Little Sunshine Bilingual Book. Kumpulan Lagu dan Cerita Anak- Anak Dwibahasa". The source of data in this research was one of text in bilingual story book for children that is "Roro Jonggrang" story. There are several steps of analyzing the data: the first is reading the text entitled "Roro Jonggrang" in "Little Sunshine Bilingual Book. Kumpulan Lagu dan Cerita Anak- Anak Dwibahasa", the second is taking note of several data that need to analyze such as the phrases or sentences in "Little Sunshine Bilingual Book. Kumpulan Lagu dan Cerita Anak- Anak Dwibahasa" stories, the third is identifying the technique of translation of "Roro Jonggrang" story in "Little Sunshine Bilingual Book. Kumpulan Lagu dan Cerita Anak- Anak Dwibahasa.", the fourth is observing which the technique of translation that often use in "Roro Jonggrang" story in "Little Sunshine Bilingual Book. Kumpulan Lagu dan Cerita Anak- Anak Dwibahasa" to know about the method that use in translation of this story, the last is after gaining the method that use in translation of this story, the researcher would know about ideology of this translation.
\end{abstract}

Keywords: Ideology, Method, technique of translation, culture

\section{A. Introduction}

The translation is important thing in this century for people who lack in understanding many languages because between one place with another place have different cultures, it makes the people need translation to know about the meaning of something from source language into target language. Hawkins (2012) says, culture is about the beliefs, knowledge, art, moral, and custom or the behaviors that belong to the people in society. Therefore, the culture is the crucial thing and one place with another place has different culture. According to Simatupang cited in Illahi et al (2018), translation is the process of 
changing from source language (SL) into target language (TL). SL or source language is the real language that use in the source book or the other things, while TL or target language is the language which be the goal of translation or the language that will be read by the society in target language. Warwal (2015) says, the translation is understanding the meaning of the text and the next production of the text which is equal, it is the translation that communicate th same meaning between one language to another language. It means, the process of translation need appropriate consideration to deliver the message for the people who read target text and the translation is the process of translating same meaning from one language to another language. Hendrawati \& Budiarta (2017), translation is a process of sending the meaning from one language (SL) to another language (TL). Therefore, translation is the process of changing the text from source language to target language in which pay attention to the equivalence meaning. According to Newmark (1988), translation is the process that is done by translator to translate or change the text or language from source language into target language. The equivalence meaning of translation is needed to deliver the meaning or information from source language to target language. The differences of cultre in source language and target language also make the translator confuse to maintain the culture in source language or adapt them into target language. So, in translation there are several ideologies.

According to Mason cited in Hatim, B. A. (2014), Ideology is value system, beliefs, and also the assumptions which are owned by society or particular social groups. According to Hoed cited in Suryasa et al (2019), ideology in translation is the believe about wrong or right and good or bad in translation or the appropriate translation for the society who will read the target language or target text. Therefore, ideology in translation is the values or beliefs in society who will read the target text which we must consider in translating the text. Venuti (2018) says the concept of ideology in translation is related to two opposites pole which one ideology take sides to the target langauge (domestication ideology) and the other ideology take sides to source language (foreignization ideology). Foreignizing ideology is the ideology that oriented towards "good" or "correct" translation is the translation that suitable with the expectations of readers or publishers who want to explore the culture of source text because they think the culture of source text is useful for readers or society. Domestication ideology is the ideology which has the believe if "good" or "acceptable" 
translation is the translation that suitable to taste of the readers who want the target text appropriate with their culture.

To know about ideologies in translation, the researcher must analyze the techniques and the methods in translation. According to Molina Albir (2002:509), technique of translation is the procedures to analyze or clarify about the equivalence in translation. There are 18 tecniques according to Molina Albir such as adaptation, Amplification, Borrowing, Compensation, Discursive Creation, Established Equivalent, literal Translation, Modulation, Reduction, Transposition, calque, description, generalization, linguistic amplification, linguistic compression, , particularization, substitution, and variation. However, the method in translation is about "ways" that translators use in translation process and it can influence the result of translation. Newark has the method that he call it as VDiagram which the left pole is for source language culture and the right pole is for target language.

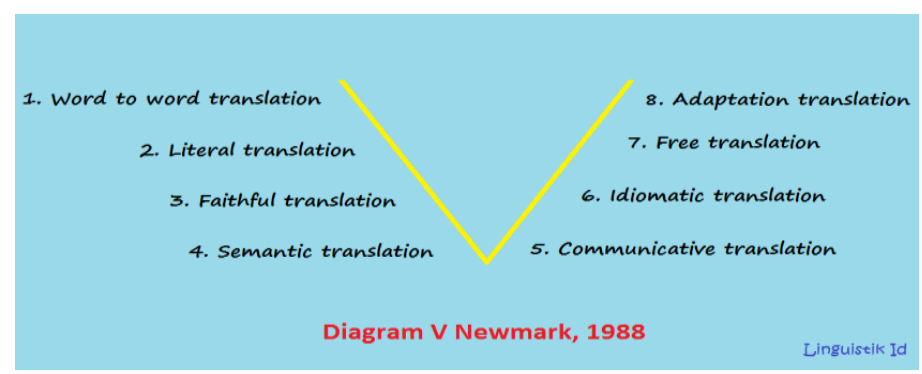

So, translation is not easy because the translator must accentuate the equivalence meaning between source language and target language. Therefore, the translator must master grammatical skill, reading skill, and discourse skill in translation process. If the translators do not have that skills, they will difficult to produce good translation.

Nowadays, there are many translation books or the other things because translation quite assist the people to understand about something. One of them is childrens' bilingual story books because translate the books which is bilingual is quite important recently such as in the bookstore there are many bilingual books that sell in that place. Beside that, children' bilingual story books also related to the children literature. Literature is includes legends, oral traditions, myths, and so on which has the artistic perspective. According to Novasyari (2019), literature is the term that use for two meanings, for the first is using for written about the subject and the second is subject that will be learned by university students. So, literature is the things that consist of stories, legends, traditions, myths, and also all of written about 
subject and the material also that will be learned by university students. Fitriana (2013) in her journal says, children literature is the appropriate book for children to read which make it with the appropriate design for children that different to adult literature because children literature is made by expert that children literature can accept by children well. The children is 6-13 years old. Santoso cited in Fitriana (2013) says if children literature must imaginatif in spoken or written that children must understand and it also close to children's world imaginatively. According to Obi (2010), children literature is the literature that write for children based on criterias such as about the heroes are children or teenager, the theme in the literature that are ideas, language, and relationship are complex or simple. Therefore, children literature is is the story that serve emotionally and psychologically that is understood by children and close to children's world imaginatively. Kind of children's literatures are poem, drama, and prose. The children literature has the function as the media in education, lead the emotions of children, and it also form students' personalities. Wahidin cited in Rahman (2011) states the function of consolation in children literature is to make the children happy to read or listen the story and it can lead their emotions. According to Puryanto cited in Fitriana (2013), the characteristics of children's literature are the content of the book has the education values, the diction is easy for children to acceppt it, the plot is easy to children, the character has good attitude, the children easy to imagine it, the setting is close to children or children easy to imagine the place, and appropriate point of view. So, if the book or literature has that characteristics, it means that book or literature is for children and children suitable to read it.

The reason why the researcher want to do this research because the researcher interests to know about the ideologies that the translator uses in this translation process for children book because as we know, translator is not easy job and the translator needs to know about the culture between source and target language to make the translation products are "good" and "acceptable" for the people who will read the target text or book. So, the researcher want to examine the ideologies that translator uses this children book.

In this research, the researcher choose "Little Sunshine Bilingual Book. Kumpulan Lagu dan Cerita Anak- Anak Dwibahasa" book because this book is published by Universitas Muhammadiyah Malang because the authors concern about the lack of material for learning in Elementary school which this book fill with the songs and short stories from tematik book 
in kurikulum 2013 which still have the limited material and learning media, and the author hopes this book can assists the students to learn more about English interestingly.

The previous observations of Ideology in Translation such as for the first is Hidayati, N.N (2020) in her journal entitled "Analysis of Translation Techniques, Methods, and Ideology on Children's Bilingual Story Book". This research is used by Newmark, Molina and Albair, and Hoed. Focuses on this research are the techniques, methods, and ideology that use in children's bilingual story book. The result of this research is many of children's bilingual story books use word by word and literal translation technique which is inappropriate because there are many errors that found in translation such as passive voice, superlative, gerunds, noun, and so on. The translators consider about foreignization ideology in this translation because it has the advantage to make the readers know about the culture in source language. The second previous observation is Fadly (2016) which is his journal entitled "Ideologi Dalam Penerjemahan Budaya: Analisis pada Novel Terjemahan "Negeri 5 Menara" Karya Ahmad Fuadi". This research is used the theories by Newmark and Venuti. Focuses on this research are techniques, methods, and ideology in Negeri 5 Menara book. The results of this research are the tecniques that often use in this book are functional equivalence and culture equivalence, the methods are adaption, free, communicative, and idiomatic. For the ideology that use in this research is more focus in domestication ideology. The third previous observation is Maryani (2019) in her journal entitled "An Analysis of Ideology and Translation Quality on Bilingual text "NANDA" English into Indonesian". This research is used the theories by Hoed, Nababan et al, and Machali. Focus on this research are ideology and translation quality in Nanda text. The results of this research are the dominant ideology that is used in this research is foreignization ideology than domestication ideology and this Nanda text has high acceptability quality in translation. The fourth previous observation is Kuncoro and Sutopo (2015) in their journal entitled "The Ideology in The Indonesian-English Translation of Cultural Terms" which translated novel Laskar Pelangi by Andrea Hirata's into The Rainbow Troops which is from Bahasa into English. The theories that are used in this research are Molina and Albir, Newmark, and Venuti. This research focuses on translation and ideology in Laskar Pelangi novel translation. The result of this research is dominant ideology in this research is domestication ideology which the techniques of tranlsation emphasize on target language. The fifth previous obersvation is Putrawan, G.E (2018) that is the journal entitled "Foreignization and Domestication of Indonesian Cultural 
Terms in The Novel Gadis Pantai Translated into English". The theories that are used in this research are Molina and Albir, Newmark, and Venuti. This research focuses on translation and ideology in Gadis Pantai novel translation.

So, there are five previous researches to support this research that related to the ideology in translation.

Refers to the explanation above, the formulation of problem in this research is What the ideologies is used by translator in translation "Little Sunshine Bilingual Book. Kumpulan Lagu dan Cerita Anak- Anak Dwibahasa" children’s bilingual book?

\section{B. Research Methodology}

In the research, research method is important thing to analyze or process the data. The researher will use descriptive qualitative method in this research because the researcher want to analyze verbal text in written form of "Little Sunshine Bilingual Book.". According to Satori and Komariah (2014), qualitative research is "describe what occur in facts". Therefore, it means if qualitative approach is the research that emphasize on quality or phenomenon in social in the field that researcher examine it. According to Creswell (2014), the are several processes of the research, namely collecting data from participants, providing question and procedures, analyzing the data, and interpreting the result of the research.

Data sources of this research is the researcher is used "Little Sunshine Bilingual Book." that is by Rina W. Setyaningrum, Rosalin I. Gusdian, Kharisma Naidi W.S, et al. which is published by Universitas Muhammadiyah Malang in 2018. It consists of 55 pages. This book tells about Indonesian's story for children that translate into English. This book also consist of moral messages for children who read this book. The researcher just analyze one story in this book that is "Roro Jonggrang."

The researcher did several steps to analyze the story in that book such as reading, taking note, and identifying the phrases or sentences in "Little Sunshine Bilingual Book." stories. Analyzing the data showed the technique, methods, and ideology that translator is used in one story in this book.

Data collecting technique in this research was the researcher collected the data through read the story of "Roro Jonggrang" in this book, take a note for the story, and clarify the result of translation that related to techniques, methods, and ideology. 
According to Sutopo cited in Nugrahani (2014), there are four characteristics of tecniques of data analysis that will use in this research:

1) Inductive. It means the researcher start with collecting the data of the research through "Little Sunshine Bilingual Book. Kumpulan Lagu dan Cerita AnakAnak Dwibahasa"

2) Analyzing the data to obtain the tecnique of translation by Molina \& Albir theory, method of tranIslation (V Newmark diagram) and ideology in translation by Venuti.

3) Serving the data that are analyzed by researcher.

4) Conclusion. It means, the researcher make the conclusion of the data that research obtained after analyzing "Little Sunshine Bilingual Book. Kumpulan Lagu dan Cerita Anak- Anak Dwibahasa"

The analyzing of the data to answer the research question or objective of the research. Several steps of analyzing the data:

1) Reading the text entitled "Roro Jonggrang" in "Little Sunshine Bilingual Book."

2) Taking note of several data that need to analyze such as phrases or sentences in "Little Sunshine Bilingual Book"

3) Identifying the technique of translation of "Roro Jonggrang" story in "Little Sunshine Bilingual Book."

4) After Observing which the technique of translation that often use in "Roro Jonggrang" story in "Little Sunshine Bilingual Book." the researcher will know about the method that is used by translator in this story.

After gaining the method that was used in translation of this story, the researcher would know about ideology of this translation.

\section{Result and Discussion}

\section{Result}

In this research, there are 62 data. This data obtained after doing the analysis of bilingual story book for children entitled "Little Sunshine Bilingual Book. Kumpulan Lagu dan Cerita Anak- Anak Dwibahasa." To obtain the technique, method, and ideology that is used in this bilingual book especially "Roro Jonggrang” story. 


\section{a. Techniques of translation}

According to Molina Albir, technique of translation is the step that related to how to analyze and clarfify the equivalence in translation. There are 18 tecniques according to Molina Albir such as adaptation, Amplification, Borrowing, Compensation, Discursive Creation, Established Equivalent, literal Translation, Modulation, Reduction, Transposition, calque, description, generalization, linguistic amplification, linguistic compression, , particularization, substitution, and variation. However, in this research, the translator just use 9 tehnique in translate "Roro Jonggrang" story from Indonesia or Bahasa to English.

The frequency of the techniques that appear in "Roro Jonggrang" story in this bilingual book for children, the highest frequency is reduction technique which is 20 data $(32,26 \%)$, and then amplfication which is 12 data (19,35\%), literal translation is 10 data $(16,13 \%)$, and then modulation is 4 data $(6,45 \%)$, generalization is 4 data $(6,45 \%)$, transposition is 4 data $(6,45 \%)$, and substitution is 4 data $(6,45 \%)$, next is established equivalent which is 2 data $(3,23 \%)$ and adaptation which is 2 data $(3,23 \%)$.

Table 1. The Percentage of Translation Techniques

\begin{tabular}{|c|c|c|c|}
\hline No & Techniques & Amount & Percentage \\
\hline 1 & Literal Translation & 10 & $16,13 \%$ \\
\hline 2 & Reduction & 20 & $32,26 \%$ \\
\hline 3 & Modulation & 4 & $6,45 \%$ \\
\hline 4 & Amplification & 12 & $19,35 \%$ \\
\hline 5 & established equivalent & 2 & $3,23 \%$ \\
\hline 6 & generalization & 4 & $6,45 \%$ \\
\hline 7 & transposition & 4 & $6,45 \%$ \\
\hline 8 & adaptation & 2 & $3,23 \%$ \\
\hline 9 & substitution & 62 data & $100 \%$ \\
\hline & Total & & $6,45 \%$ \\
\hline
\end{tabular}

1) Reduction 
Reduction is the technique that the translator is used many times in this bilingual book especially in "Roro Jonggrang" story which is 20 data. The reduction technique is when the translator ommite words, phrases, or sentences from source language to target language because the ommision does not emerge the distortion of meaning. Several samples of data in this research that are used reduction technique:

a) ---Raja Prambanan, ayah Roro Jonggrang gugur dalam pertarungan melawan Bandung Bondowoso dari Kerajaan Pengging, Akibatnya, Bandung Bondowoso menguasai Kerajaan Prambanan--- = The King of Prambanan, Roro Jonggrang's father, died in a battle against Bandung Bondowoso from Pengging Kingdom. This sentences use reduction technique because the sentence in source language that is "Akibatnya, Bandung Bondowoso menguasai kerajaan Prambanan" does not emerge in target language and does not make the distortion of meaning.

b) Namun, jika gagal izinkan aku pergi." Kata Roro Jonggrang= If you fail let me go. This sentences use reduction technique because the sentence in source language that is "Namun" does not emerge in target language and does not make the distortion of meaning.

2) Amplification

Amplification is the technique that the translator is used in this bilingual book especially in "Roro Jonggrang" story which is 12 data. Amplification is the translation technique which make the data in source language to be more explicit in target language and also adding some linguistic elements in target language.

Several samples of data in this research that are used amplification technique:

a) "aku akan mengembalikan kerajaan ini untukmu"= "I will not only let you go, but also I will return the kingdom." This sentence use amplification technique because the translator adds linguistic element in this sentence and make it more explicit with the sentence "I will not only let you go" that add in target language.

b) Mendengar kokok ayam jantan, pasukan jin terkejut $=$ Hearing the crow, the formation of devil shocked. The think that the morning has come. This sentence use amplification technique because the translator adds linguistic element in this sentence and make it more explicit with the sentence "The think that the morning has come" that add in target language.

3) Literal translation 
Literal translation is the technique that the translator is used in this bilingual book especially in "Roro Jonggrang" story which is 10 data. Literal translation is the translator translates word by word without related it with the context.

Several samples of data in this research that are used literal translation technique:

a) Roro Jonggrang panik= Roro Jonggrang is panic.

b) Jawab Bandung Bondowoso = answer Bandung Bondowoso. = literal translation.

4) Modulation

Modulation is the technique that the translator is used in this bilingual book especially in "Roro Jonggrang" story which is 4 data. Modulation is the translation technique which change the point of view, cognitive categories or focus that related to source language.

Several samples of data in this research that are used modulation technique:

a) sebelum matahari terbit esok = in one night. It uses modulation because changing the point of view from "sebelum matahari terbit esok" in source language to be "in one night".

b) Roro Jonggrang yang tidak mau diperistri oleh Bandung Bondowoso --- = --Roro Jonggrang does not want to marry him. In here, the translator uses modulation technique because changing the point of view from "Roro Jonggrang yang tidak mau diperistri oleh Bandung Bondowoso" to be "Roro Jonggrang does not want to marry him".

5) Generalization

Generalization is the technique that the translator is used in this bilingual book especially in "Roro Jonggrang" story which is 4 data. Generalization is the translation technique which changing the common term in source language to specific term in target language. The reason of it because in target language, there is no term that equivalence and specific.

Sample of data in this research that is used generalization technique:

"---kau menjadi candi keseribu." = "--- you to be a stone" = It uses generalization because the word "candi" there is no that term in target language, so the translator change it into "stone".

6) Transposition 
Transposition is the technique that the translator is used in this bilingual book especially in "Roro Jonggrang" story which is 4 data. Transposition is the translation technique which changing grammatical categories.

Sample of data in this research that is used transpositionn technique:

--untuk menggagalkan pekerjaan Bandung Bondowoso= --to make Bandung Bondowoso fail= It uses transposition technique because there is changing the grammatical categories.

7) Substitution

Substitution is the technique that the translator is used in this bilingual book especially in "Roro Jonggrang" story which is 4 data. Substitution is the translation technique which changing the elements in linguistics and paralinguistic such as gesture or intonation.

Sample of data in this research that is used substitution technique:

"-- kuubah kau menjadi candi keseribu." = "-- curse you to be a stone." = It uses substitution because the word "ubah" in source language changes to "curse (mengutuk)".

8) Established equivalent

Established equivalent is the technique that the translator is used in this bilingual book especially in "Roro Jonggrang" story which is 2 data. Established equivalent is the translation technique which using the term that is equivalence in target language based on dictionary or the term that using in daily life.

Sample of data in this research that is used established equivalent technique:

"Dengan kesaktiannya ---"= "With his power---" = It uses establish equivalent because the word "kesaktiannya" change itu "his power" in target language because the word "kesaktian" will equivalence in target language if the translator use "power".

9) Adaptation

Adaptation is the technique that the translator is used in this bilingual book especially in "Roro Jonggrang" story which is 2 data. Adaptation is the translation technique which changing the culture elements in source language into the culture that similar or adjust with target language

Sample of data in this research that is used adaptation technique: 
Dia segera memerintahkan para dayang--- $=$ She gives govern to other servants---= It uses adaptation because the word "dayang" is the word in source language and it is similar with "servant" in target language.

\section{b. Translation Methods}

Newmark (1988) divides two kinds of method in translation. First, the method that is emphasizes on source language. Second, the method that is emphasizes on target language such as:

\section{SL Emphasis}

Word-for-word translation

Literal translation

Faithful translation

Semantic translation
TL Emphasis

Adaptation

Free translation

Idiomatic translation

Communicative translation

In this research there are 62 data with the detail such as:

Table 2. The Percentage of Translation Techniques

\begin{tabular}{|c|c|c|c|}
\hline No & Techniques & Amount & percentage \\
\hline 1 & Literal Translation & 10 & $16,13 \%$ \\
\hline 2 & Reduction & 20 & $32,26 \%$ \\
\hline 3 & Modulation & 4 & $6,45 \%$ \\
\hline 4 & Amplification & 12 & $19,35 \%$ \\
\hline 5 & established equivalent & 2 & $3,23 \%$ \\
\hline 6 & generalization & 4 & $6,45 \%$ \\
\hline 7 & transposition & 4 & $6,45 \%$ \\
\hline 8 & adaptation & 2 & $3,23 \%$ \\
\hline 9 & substitution & 62 data & $6,45 \%$ \\
\hline & Total & 4 & $100 \%$ \\
\hline
\end{tabular}

Based on the tabel above there are 9 techniques that the translator uses in this children's bilingual book especially in "Roro Jonggrang" story. There are literal translation, reduction, modulation, amplificaion, establish equivalent, generalization, transposition, adaptation, and substitution. 
The frequency of the techniques that appear in "Roro Jonggrang" story in this bilingual book for children, the highest frequency is reduction technique which is 20 data $(32,26 \%)$, and then amplfication which is 12 data (19,35\%), literal translation is 10 data $(16,13 \%)$, and then modulation is 4 data $(6,45 \%)$, generalization is 4 data $(6,45 \%)$, transposition is 4 data $(6,45 \%)$, and substitution is 4 data $(6,45 \%)$, next is established equivalent which is 2 data $(3,23 \%)$ and adaptation which is 2 data $(3,23 \%)$.

Table 3. The Percentage of Translation Techniques that emphasize on source language

\begin{tabular}{|c|c|c|c|}
\hline No & Techniques & Amount & percentage \\
\hline 1 & Literal Translation & 10 & $16,13 \%$ \\
\hline & Total of data & 62 & $16,13 \%$ \\
\hline
\end{tabular}

Table 4. The Percentage of Translation Techniques that emphasize on target language

\begin{tabular}{|c|c|c|c|}
\hline No & Techniques & Amount & percentage \\
\hline 1 & Reduction & 20 & $32,26 \%$ \\
\hline 2 & Modulation & 4 & $6,45 \%$ \\
\hline 3 & Amplification & 12 & $19,35 \%$ \\
\hline 4 & established equivalent & 2 & $3,23 \%$ \\
\hline 5 & generalization & 4 & $6,45 \%$ \\
\hline 6 & transposition & 4 & $6,45 \%$ \\
\hline 7 & adaptation & 4 & $3,23 \%$ \\
\hline 8 & substitution & 62 data & $83,87 \%$ \\
\hline
\end{tabular}

Based on the tables above, we can conclude if the data that is used technique which emphasizes on source language there is $16,13 \%$ and the data that is used technique which emphasizes on target language there is $83,87 \%$. So, the book "Little Sunshine Bilingual Book. Kumpulan Lagu dan Cerita Anak- Anak Dwibahasa" especially "Roro Jonggrang" story use translation methods that empasize on target language with the detail of the data:

Table 5. The Percentage of Translation Techniques, Methods, and Ideology

\begin{tabular}{|c|c|c|c|}
\hline Techniques & Percentage & Method & Ideology \\
\hline
\end{tabular}




\begin{tabular}{|c|c|c|c|}
\hline Literal translation & $16,13 \%$ & Literal translation & Foreignization \\
\hline Reduction & $32,26 \%$ & Free translation & Domestication \\
\hline Modulation & $6,45 \%$ & $\begin{array}{c}\text { Communicative } \\
\text { translation }\end{array}$ & Domestication \\
\hline Amplification & $19,35 \%$ & Free translation & Domestication \\
\hline established equivalent & $3,23 \%$ & Idiomatic & Domestication \\
translation & \\
\hline generalization & $6,45 \%$ & $\begin{array}{c}\text { Communicative } \\
\text { translation }\end{array}$ & Domestication \\
\hline transposition & $6,45 \%$ & $\begin{array}{c}\text { Communicative } \\
\text { translation }\end{array}$ & Domestication \\
\hline adaptation & $3,23 \%$ & Idiomatic & Domestication \\
& & translation & \\
\hline substitution & $6,45 \%$ & Idiomatic & Domestication \\
& & translation & \\
\hline
\end{tabular}

Domestication ideology is the translator use the ideology in translation that emphasizes on target language.

\section{c. Ideology of Translation}

The ideology of translation is seen by principle of translator in translation something. The researcher can identify the ideology that is used by translator through the techniques and the methods that translator use in translation the book or something. After that, the researcher will get the data about the ideology that translator uses in book.

If the translator use the ideology that emphasizes on source language, it means the translator uses foreignization ideology. However, if the translator use the ideology that emphasizes on target language, it means the translator uses domestication ideology. What the ideology that translator uses in book or something, it depends on the translator's decision.

Foreignization ideology apply these methods:

2) Word-for-word translation

1) Literal translation

3) Faithful translation

4) Semantic translation 
Foreignization ideology apply these techniques:
1) Literal translation
2) Borrowing
3) Pure borrowing
4) Calque

However, domestication ideology apply these methods:
1) Adaptation
2) Free translation
3) Idiomatic translation
4) Communicative translation

Domestication ideology apply these techniques:

1) Adaptation
2) Amplification

3) Compensation

4) Discursive Creation

5) Established Equivalent

6) Modulation

7) Reduction

8) Transposition

9) Description

10) Generalization

11) linguistic amplification

12) linguistic compression

13) particularization

14) substitution

15) variation.

Table 6. The Percentage of Translation Techniques in foreignization ideology

\begin{tabular}{|c|c|c|}
\hline Techniques & Percentage & Ideology \\
\hline Literal translation & $16,13 \%$ & Foreignization \\
\hline
\end{tabular}

Table 7. The Percentage of Translation Techniques in Domestication ideology

\begin{tabular}{|c|c|c|}
\hline Techniques & Percentage & Ideology \\
\hline Reduction & $32,26 \%$ & Domestication \\
\hline Modulation & $6,45 \%$ & Domestication \\
\hline Amplification & $19,35 \%$ & Domestication \\
\hline established equivalent & $3,23 \%$ & Domestication \\
\hline generalization & $6,45 \%$ & Domestication \\
\hline transposition & $6,45 \%$ & Domestication \\
\hline adaptation & $3,23 \%$ & Domestication \\
\hline substitution & $6,45 \%$ & Domestication \\
\hline
\end{tabular}


Table 8. The Percentage of Translation Techniques, Methods, and Ideology in foreignization ideology

\begin{tabular}{|c|c|c|c|c|}
\hline No & Techniques & Percentage & Method & Ideology \\
\hline 1 & Literal translation & $16,13 \%$ & $\begin{array}{c}\text { Literal } \\
\text { translation }\end{array}$ & Foreignization \\
\hline \multicolumn{2}{|c|}{ Total } & & $16,13 \%$ & \\
\hline
\end{tabular}

Table 9. The Percentage of Translation Techniques, Methods, and Ideology in Domestication ideology

\begin{tabular}{|c|c|c|c|c|}
\hline No & Techniques & Percentage & Method & Ideology \\
\hline 1 & Reduction & $32,26 \%$ & Free translation & Domestication \\
\hline 2 & Modulation & $6,45 \%$ & $\begin{array}{c}\text { Communicative } \\
\text { translation }\end{array}$ & Domestication \\
\hline 3 & Amplification & $19,35 \%$ & Free translation & Domestication \\
\hline 4 & $\begin{array}{l}\text { established } \\
\text { equivalent }\end{array}$ & $3,23 \%$ & $\begin{array}{l}\text { Idiomatic } \\
\text { translation }\end{array}$ & Domestication \\
\hline 5 & generalization & $6,45 \%$ & $\begin{array}{c}\text { Communicative } \\
\text { translation }\end{array}$ & Domestication \\
\hline 6 & transposition & $6,45 \%$ & $\begin{array}{c}\text { Communicative } \\
\text { translation }\end{array}$ & Domestication \\
\hline 7 & adaptation & $3,23 \%$ & $\begin{array}{l}\text { Idiomatic } \\
\text { translation }\end{array}$ & Domestication \\
\hline 8 & substitution & $6,45 \%$ & $\begin{array}{l}\text { Idiomatic } \\
\text { translation }\end{array}$ & Domestication \\
\hline & Total & \multicolumn{3}{|c|}{$83,87 \%$} \\
\hline
\end{tabular}

\section{Discussion}

The translator in "Little Sunshine Bilingual Book. Kumpulan Lagu dan Cerita AnakAnak Dwibahasa" especially in "Roro Jonggrang" story uses techniques and methods of translation that emphasize on target language rather than source language, so because techniques and methods that emphasieze on the target language, it can concludes that the 
translator uses translation ideology that is domestication ideology with the result that is 83,87\%. The result of this research is also similar and supported by Fadly (2016) in his journal entitled "Ideologi Dalam Penerjemahan Budaya: Analisis pada Novel Terjemahan "Negeri 5 Menara" Karya Ahmad Fuadi" which they analyzed the story from soure language that is Bahasa into target language that is English which is same with this research that also use the book that translate from Bahasa to English. The results of his research are the tecniques and methods that often use in this book emphasize on target language rather than source language. For the ideology that use in this research is more focus in domestication ideology which want the reader in target language can understand clearly about the translation book. The result of his research is same with this research which is the translator use domestication ideology because the technique and method that emphasize on target language. Beside that, his research is used theories by Newmark and Venuti, while this research is used theories by Molina \& Albir, Newmark and Venuti. The differences between his research with this research is the kind of book because Fadly analyzed the novel, however this research analyze the bilingual book for children. In addition, the research by Putrawan, G.E (2018) that is journal entitled "Foreignization and Domestication of Indonesian Cultural Terms in The Novel Gadis Pantai Translated into English" also support this research because the result of Putrawan's research is the dominant ideology that is used by translator is domestication ideology because the technique and method that emphasize on target language. Beside that, between their research with this research also have similarity that is used theories by Newmark and Venuti. The differences between his research with this research is the kind of book because Putrawan analyzed the novel, however this research analyze the bilingual book for children. Kuncoro and Sutopo (2015) in their journal entitled "The Ideology in The Indonesian-English Translation of Cultural Terms" which translated novel Laskar Pelangi by Andrea Hirata's into The Rainbow Troops which is from Bahasa into English also support this research because in their journal the result of dominant ideology is domestication ideology which the techniques of tranlsation emphasize on target language. Beside that, between their research with this research also have similarity that is used theories by Newmark and Venuti. The differences between their research with this research is this research analyzed the novel, however this research analyze the bilingual story book for children. 


\section{Conclusion}

Based on the analysis above, the researcher obtains the data about the techniques, methods, and ideology of translation that translator uses in "Little Sunshine Bilingual Book. Kumpulan Lagu dan Cerita Anak- Anak Dwibahasa" especially in "Roro Jonggrang" story. The conclusions of this research are the techniques of translation that translator use in this books that are reduction technique which is 20 data $(32,26 \%)$, and then amplfication which is 12 data $(19,35 \%)$, literal translation is 10 data $(16,13 \%)$, and then modulation is 4 data $(6,45 \%)$, generalization is 4 data $(6,45 \%)$, transposition is 4 data $(6,45 \%)$, and substitution is 4 data $(6,45 \%)$, next is established equivalent which is 2 data $(3,23 \%)$ and adaptation which is 2 data $(3,23 \%)$. The most highest frequency of translation technique that translator use in "Little Sunshine Bilingual Book. Kumpulan Lagu dan Cerita Anak- Anak Dwibahasa" especially in "Roro Jonggrang" story is reduction with 20 data $(32,26 \%)$ that show if the translator use the technique that emphasizes on target language rather than source language which the translator tried to make the reader in target language is easier to read the target text rather than introduce the culture in source language. However, the translator rare to use established equivalent with 2 data $(3,23 \%)$ and adaptation which is 2 data $(3,23 \%)$. The total of percentage of the techniques that emphasize on source language is $16,13 \%$ and the total of percentage of the tecniques that emphasizes on target language is $83,87 \%$. So, from the data, the translator more often to use the tecniques of translation that emphasizes on target language such as reduction, amplification, modulation, generalization, transposition, substitution, established equivalent, adaptation. After the researcher obtained that data of translation techniques that translator uses in this book, the researcher also obtained the data of the translation methods that translator uses in "Little Sunshine Bilingual Book. Kumpulan Lagu dan Cerita Anak- Anak Dwibahasa" especially in "Roro Jonggrang" story are literal translation, free translation, communicative translation, and idiomatic translation. Literal translation method emphasizes on source language, while free translation, communicative translation, and idiomatic translation emphasize on target language. The total of percentage of the methods that emphasize on source language is $16,13 \%$ and the total of percentage of the methods that emphasizes on target language is $83,87 \%$. In order, after the reseacrher obtained the data about techniques and methods in translation, the researcher also obtained the data of the ideology that translator use in "Little Sunshine Bilingual Book. Kumpulan Lagu dan 
Cerita Anak- Anak Dwibahasa" especially in "Roro Jonggrang" story that are domestication ideology with the percentage of data is $83,87 \%$, the domestication ideology emphasizes on target language. However, the foreignization ideology with the percentage of the data is $16,13 \%$, the foreignization ideology emphasizes on source language. So, after analyzing the techniques and methods, the most ideology that translator use in "Little Sunshine Bilingual Book. Kumpulan Lagu dan Cerita Anak- Anak Dwibahasa" especially in "Roro Jonggrang" story is domestication ideology with the percentage of data is $83,87 \%$.

\section{References}

Creswell, J. W. (2014). Research design: qualitative, quantitative and mixed methods approaches: fourth edition. Thousand Oaks, CA: Sage Publications

Fadly, A. (2016). Ideologi dalam penerjemahan budaya: analisis pada novel terjemahan "negeri 5 menara" karya ahmad fuadi. Jurnal Pendidikan Bahasa dan Sastra, 16(2), 132143.

Fitriana, I. (2013). Penerjemahan karya sastra anak.

Hatim, B. A. (2014). Teaching and researching translation. Routledge.

Hawkins, P. (2012). Creating a coaching culture. New York: Bell and Bain Ltd.

Hendrawati., \& Budiarta. (2017). The translation of idiomatic expression in bloodline into "garis darah". Jurnal Ilmu Bahasa, 3(2), 228-238

Hidayati, N.N (2020). Analysis of translation techniques, methods, and ideology on children's bilingual story books. 3 (2), .96-114.

Illahi., Ras., \& Hadriana. (2018). An analysis of english study program sixth-semester students' translation quality in translating english phrasal verbs into indonesian. Jom Fkip - Ur Volume 5.

Maryani. (2019). An analysis of ideology and translation quality on bilingual text "nanda" english into indonesian. Journal of English Education

Molina, L \& Albir.A.H. (2002). Translation technique revisited: a dynamic and Fuctioalist approach

Newmark, P. (1988). Introduction to translation. Prentice-hall international. New York: Prentice-Hall International. https://doi.org/10.4161/trla.24611.

Novasyari, R. (2019). Significant Roles Of Children's Literature In Efl. Global Expert Jurnal Bahasa dan Sastra Volume 8 No.1 Juli 2019 Issn Print : 2303-5328 ISSN Online : 24773794

Nugrahani, F. (2014). Metode penelitian kualitatif dalam penelitian pendidikan bahasa. Solo: Cakra Books

Obi C. Et. al. (2010). Children's literature. Nigeria: National Open University of Nigeria.

Putrawan, G.E. (2018). Foreignization and domestication of Indonesian cultural terms in the novel Gadis Pantai translated into English. Lingua Cultura, 12(3), 309-315

Rahman, F. (2011). Sastra anak dalam persimpangan. Published In Humaniora Tamalanrea 
Rina W. Setyaningrum, Rosalin I. Gusdian, Kharisma Naidi W.S, et al. (2018). Little sunshine bilingual book kumpulan lagu dan cerita anak- anak dwibahasa. Malang: Penerbit Universitas Muhammadiyah Malang.

Satori, D., \& Komariah, A. (2014). Metodologi Penelitian Kualitatif. Alfabeta, CV: Bandung

Suryasa, I. W., et al. (2019). Translation of Krsna text and ideology." International Journal of Social Sciences and Humanities, vol. 3, no. 1, Apr. 2019, pp. 36-47, doi:10.29332/ijssh.v3n1.251.

Venuti, L. (2018). The translator's invisibility:a history of translation (Third Edition). London: Routledge.

Warwal, S. (2015). Translation process and problem of translation in world classics. Indian Scholar An International Multidisciplinary Research e-Journal. 1. 125-133. 